\title{
ЗАРИМ ТӨРЛИЙН ЦАЙНЫ НИЙЛБЭР ФЛАВОНОИДЫН АГУУЛГЫГ СПЕКТРОФОТОМЕТРИЙН АРГААР ТОДОРХОЙЛОХ
}

\author{
М. Биндэръяа ${ }^{1}$, М.Бөхчулуу ${ }^{2}$, Э. Энхсурэн \\ ${ }^{1}$ ШУА-ийн Физик Технологийн ХУрээлэн \\ ${ }_{2}^{2}$ УКТЭ-ийн Гемодиализийн төв
}

\begin{abstract}
The guantitative determination of total flavonoids in widely used teas and in their agueous $96 \%$ etanolic extracts and were carried out using direct and differential spectrophotometry methods, recpectively. The content of total flavonoids of Akbar tea $5.67 \%$, of Дагвa-18 tea $5.11 \%$, Japan tea $5.02 \%$ maximum dosages, recpectively.

ТҮлхҮҮр Үг: флавоноид, ХЯГ-ийн спектр, катехин

\section{ОРШИЛ}

Байгалийн гаралтай биологийн идэвхт бага молекулт нэгдлийн антиоксидант идэвхийг тодорхойлох, бүтэц, биологи үйлчлэлийн шүтэлцээг тогтоох нь молекул спектроскопи, молекул биофизикийн анхаарал татсан, шийдвэрлэх асуудлын нэг юм. Энэ судалгаa макромолекул (уураг), бага молекулт нэгдлийн харилцан үйлчлэлийн механизмыг тайлбарлахаас гадна эмнэлэг биологи, хүнс тэжээл, эрүүл ахуйтай холбоотой практик өгөөжтэй төрөлхтөний юугаар ч сольшгүй мөнхийн хэрэгцээт бүтээгдэхүүн. Цайны катехин гидролизод ордоггүй идээлэгч бодис бөгөөд хэд хэдэн катехинууд болон тэдгээрийн галлийн эфирийн хольц байдлаар байдаг. Хольцийн гол компонентүүд: L-эпикатехин, L- галлокатехин, тэдгээрийн галлийн хүчлийн эфирүүд болно. Жнь: Цейлон цайны навчинд L-эпикатехин $6.5 \%$, галлокатехин $24.2 \%$, эпикатехингаллат 9\%, галлокатехингаллат 49\% агуулагддаг.
\end{abstract}

ажил юм. Цай, цайны бүтээгдэхүүн нь хүн

\section{Цайны катехин}

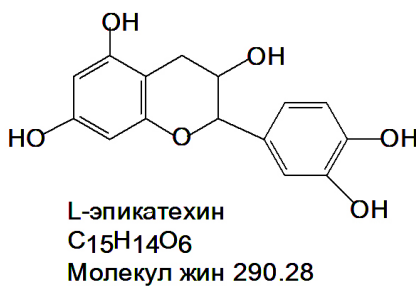

Ногоон цайны хуурай жингийн 22-24\%, хар цайны $14-17 \%$ идээлэгч бодисууд байна. Сул хүчлийн орчинд нягтаршин тунадасжиж флобафен үүсгэнэ. Организмд Р-витамины үйлчлэлийг үзүүлэх ба судасны хананы нягтралыг ихэсгэж, витамин

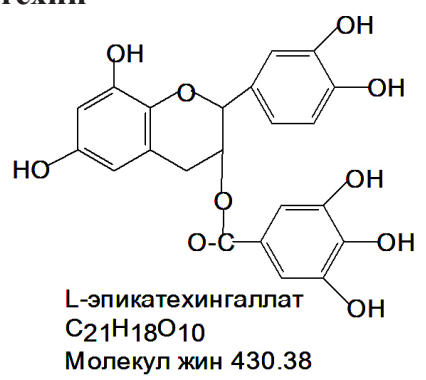

С-гийн хуримтлалыг нэмэгдүүлэх, хорт хавдар, зүрх судасны өвчлөлийг бууруулах үйлчилгээтэй. Ногоон цай чөлөөт радикалуудыг саармагжуулах үйлчлэлтэй тул хүний бие махбодийг хөгшрүүлэх, өвчин үүсгэХ хортой нөлөөнөөс эд эсийг 
хамгаалдаг полифенолт флавоноидуудыг их хэмжээгээр агуулахаас гадна ямар ч өөх тосны найрлагагүй сайн талтай.[2,3,4]

\section{Судалгааны материал, арга зүй}

Дагва-18 цай, ходоодны цай, ивээл цай, зүрхний цай, бөөрний цай, тамир цай, дархлаа сэргээх цай, хоргүйжүүлэх цай, элэг хамгаалах цай, аквар цай, япон ногоон цай, хятад ногоон цай, липтон цай, импра цай, солонгос цай, хөвсгөл цай, таван богд ногоон цай дээжүүдийг судалгаанд хэрэглэлээ.

Цайнуудын нийлбэр флавоноидыг спектроскопийн аргаар тодорхойлохын тулд 1г ургамлын дээж (1мм диаметртэй болтол нь нунтаглаж шигшсэн ургамлын дээж) жигнэн авч, 250 мл-ийн шлифтэй колбонд хийн, 200мл 96\%-ийн этилийн спирт нэмж, усан банн дээр эргэх хөргөгчтэй холбон 2 цагийн турш хандлалт явуулна. Хандаа хөргөж шүүгээд, анхны эзлэхүүн хүртэл нь этилийн спирт нэмнэ. 2-4 мл ханд хөвөн дундуур шүүж, 25 мл-ийн колбонд хийгээд 2.5 мл $1 \mathrm{M} \mathrm{AeCl}$-ийн 96\%-ийн этанолд уусгасан уусмалаас нэмэн, хэмжүүр хүртэл нь концентрацитай этанол нэмнэ. Зэрэгцээ колбонд ургамлын ханднаасаа 2-4 мл-ийг авч, 1 дусал 1\%-ийн $\mathrm{HCl}$ нэмэн, 25 мл болтол нь концентрацитай этанол хийн жиших уусмал бэлтгэнэ. 30 минутын дараа бэлтгэсэн уусмалуудын оптик нягтыг Япон улсын Shimadzu корпорацийн UV-2550 спектрофотометрийн 406 нм-т (стандарт бодисоор рутин сонгосон тохиолдолд) долгионы уртад 10мм-ийн зузаантай кварцан кювет ашиглан хэмжилт хийв. Стандарт рутины $0.025 \%$-ийн этилийн спиртэн уусмал бэлтгээд, 2-4 мл-ийг хэмжин авч, ургамлын хандаас спектрт бэлтгэсэнтэй адил уусмал бэлтгэн, хэмжилт хийнэ. Бэлтгэсэн уусмалын оптик нягтыг 406 нм долгионы мужид хэмжинэ. Хэмжилтийн дүнгүүдийг дараахь томъёонд орлуулан нийлбэр флавоноидын агуулгыг тодорхойлно. [1,5,6,7,8]

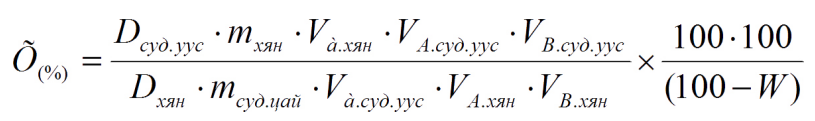

$\mathrm{X}_{(\%)}$-нийлбэр флавоноидын процентын

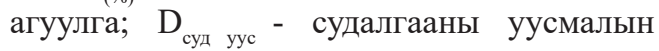
гэрлийн нягт; $D_{\text {хян }}$ - стандарт уусмалын гэрлийн нягт, $\mathrm{m}_{\text {хян }}$ - стандарт бодисын хэмжээ (граммаар); $m_{\text {суд цай }}$ - шинжилгээний ургамлын хэмжээ (граммаар); $\mathrm{V}_{\text {а.хян }}-\mathrm{V}_{\mathrm{A}}$ - стандарт уусмалаас авсан хэмжээ (млээр); $\mathrm{V}_{\text {а.суд.уус }}$ - Эх уусмалаас $\left(\mathrm{V}_{\mathrm{A}}\right)$ багананд шингээсэн дээжний хэмжээ (мЛ); $\mathrm{V}_{\text {А.суд.уус }}$ гидролизод оруулсан судалгааны уусмалын эзлэхүүн (мл); $\mathrm{V}_{\text {А.хян }}$ - стандарт уусмалын эзЛэХҮҮН (мЛ); $\mathrm{V}_{\text {В.суд.уус }}-$ оптик нягтыг нь хэмжих судалгааны уусмалын эзлэхүүн (мЛ); $\mathrm{V}_{\text {В.хян }}$ - оптик нягтыг нь хэмжих стандарт уусмалын эзлэхүүн (мл); W- чийг (\%).

Чийг тодорхойлох: Зохих стандартын дагуу түүж, хатааж, нунтагласан 3-5 г ургамлын дээжийг жинг нь тогтмолжуулсан бюксэнд хийгээд, хатаах шүүгээнд 100$105^{\circ} \mathrm{C}$-д тавина. 2 цагийн дараа эхний жигнэлтээ хийнэ. Түүхий эдийн жинг тогтмолжтол, жигнэлт хоорондын жингийн зөрүү 0.0005 г болтол хатаана.

$$
W=\frac{\left(m-m_{1}\right) \cdot 100}{m}
$$

W- жингийн процентийн агуулга, m-хатаахын өмнөх түүхий эдийн жин; $\mathrm{m}_{1}$-хатаасны дараах түүхий эдийн жин; Сүүлчийн үр дүнг 2 зэрэгцээ жигнэлтийн дунджаар авна.

\section{Судалгааны ажлын үр дүн}

Сонгосон ургамлуудын спиртэн хандны нийлбэр флавоноидын агуулгыг тооцохын тулд стандарт бодисоор рутиныг авлаа. Стандарт рутины максимум шингээлт 2-p зурваст 274 нм, 1-р зурваст 406 нм-т өгчээ (зураг 1). Судалгааны ургамлуудын чийгийн агуулга, флавоноидын процентийн агуулгыг хүснэгт 1-д үзүүлэв [1,9,10]. 
Хүснэгт 1 .

Судалгааны ургамлуудын нийлбэр флавоноидын тоон тодорхойлолт

\begin{tabular}{|c|l|c|c|c|}
\hline № & \multicolumn{1}{|c|}{ Цайны дээж } & $\begin{array}{c}\text { Судалгааны } \\
\text { ургамлуудын } \\
\lambda=406 \text { дам дахь оптик } \\
\text { нягтын (D) утга }\end{array}$ & $\begin{array}{c}\text { Судалгааны } \\
\text { ургамлуудын } \\
\text { чийгийн агуулга } \\
\text { (\%-иор) }\end{array}$ & $\begin{array}{c}\text { Нийлбэр } \\
\text { флавоноидын } \\
\text { агуулга C, } \\
\% \text {-иор }\end{array}$ \\
\hline 1 & Аквар & 0.89 & 6.26 & 5.67 \\
\hline 2 & Дагва-18 цай & 0.841 & 6.23 & 5.11 \\
\hline 3 & Япон ногоон цай & 0.798 & 5.08 & 5.02 \\
\hline 4 & Хятад ногоон цай & 0.798 & 2.91 & 4.91 \\
\hline 5 & Липтон & 0.59 & 5.8 & 3.74 \\
\hline 6 & Импра & 0.589 & 6.27 & 3.73 \\
\hline 7 & Ходоодны цай & 0.586 & 5.34 & 3.52 \\
\hline 8 & Ивээл цай & 0.549 & 5.64 & 3.31 \\
\hline 9 & Зүрхний цай & 0.507 & 4.27 & 3.07 \\
\hline 10 & Солонгос цай & 0.46 & 4.9 & 2.89 \\
\hline 11 & Бөөрний цай & 0.435 & 5.35 & 2.61 \\
\hline 12 & Тамир цай & 0.397 & 6.12 & 2.4 \\
\hline 13 & Хөвсгөл цай & 0.338 & 5.82 & 2.04 \\
\hline 14 & Дархлаа сэргээх цай & 0.352 & 6.8 & 2.25 \\
\hline 15 & Бөөрний цай-1 & 0.313 & 5.21 & 1.88 \\
\hline 16 & Хоргүйжүүлэх цай & 0.237 & 5.27 & 1.42 \\
\hline 17 & Таван богд шахмал ногоон цай & 0.153 & 6.51 & 0.97 \\
\hline 18 & Элэг хамгаалах цай & 0.126 & 5.35 & 0.75 \\
\hline
\end{tabular}

Нийлбэр флавоноидын агуулгыг графикаар үзүүлбэл:

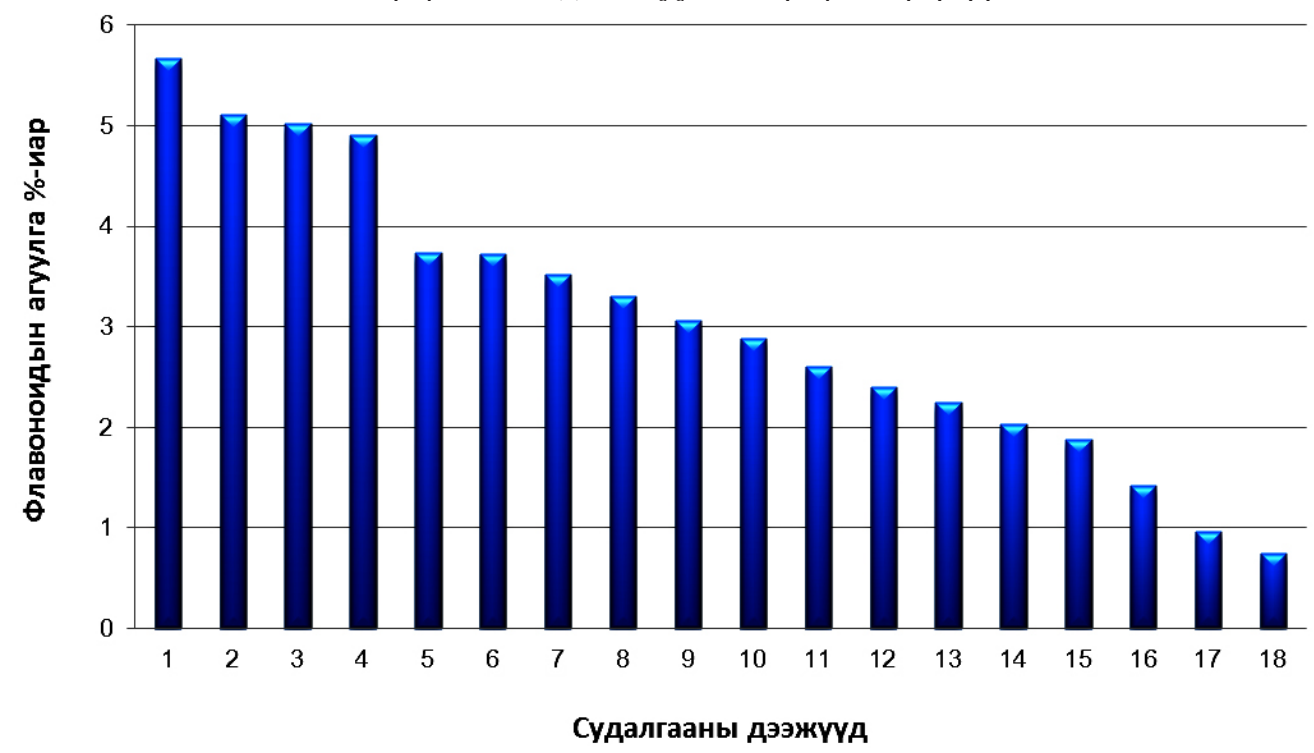

1.Аквар изай, 2. Дагва-18 иай, 3.Япон ногоон иай, 4.Хятад ногоон цай, 5.Липтон иай, 6.Импра ияай,

7. Ходоодны иай, 8. Ивээл цай, 9. Зүрхний цай, 10.Солонгос изай, 11. .Бөөрний цай, 12.Тамир цай,

13.Хөвсгөл цай, 14.Дархлаа сэргээх иай, 15.Бөөрний цай-1, 16.Хоргүйжүүлэх ияай, 17.Таванбогд иай, 18.Элэг хамгаалах иай. 


\section{Дүгнэлт}

1. 18 төрлийн эмчилгээний болон ахуйн хэрэглээнй цайнуудын нийлбэр флавоноидын агуулгыг спектрофотометрийн аргаар тодорхойллоо.

2. Судалгааны дүнгээс үзэхэд нийлбэр флавоноидын агуулга харьцангуй өндөртэй нь аквар цай (5.67\%), дагва-18 цай $(5.11 \%)$, япон ногоон цай $(5.02 \%)$, хятад ногоон цай $(4.91 \%)$, харьцангуй

багатай нь хоргүйжүүлэх цай (1.88\%), таванбогд шахмал ногоон цай $(0.97 \%)$, элэг хамгаалах цай $(0.75 \%)$ байлаа.

3. Эмчилгээний идэвхтэй дагва 18 цай (5.11\%), ходоодныцай $(3.52 \%)$, бөөрний цай $(2.61 \%)$, тамир цай $(2.4 \%)$, дархлаа сэргээх цай $(2.04 \%)$, хоргүйжүүлэх цай $(1.88 \%)$, элэг хамгаалах цайны $(0.75 \%)$ флавоноидын агуулга харьцангуй их ч, хоорондоо ялгаатай байна.

\section{Ашигласан бүтээлийн жагсаалт:}

1. Биндэръяа М, Эмийн 2 зүйл ургамлаас ялгасан биологийн идэвхт бодисын химийн судалгаa, доктор Ph.D зэрэг горилсон бүтээл, УБ 2003 он.

2. Лигаа У, Даваасүрэн Б, Нинжил Н, Монгол орны эмийн ургамлыг Өрнө Дорнын анагаах ухаанд хэрэглэхүй, УБ, 2005, ху 251, 250, 252, 326.

3. Хайдав Ц, Меньшикова Т.А, Лекарственные растения в Монгольской медицине, УБ, 1978, стр 144-146.

4. Хайдав Ц, Алтанчимэг Б, Варламова Т.С, Лекарсвенные растения в Монголской медицине, УБ, 1985, стр 171-176.

5. В.В. Беликов, Оценка содержания флаванонол-производных в флодах Silybum marianum (L) Gaertn., Растительные ресурсы выпуск '3, том 21, стр 355-358, 1985.

6. Г.И. Высочина, Ю.В.Шинкаренко, Т.А. Кукушкина, Содержание флавоноидов в растениях лисостепной зоны западной Сибири, Химия в интересах устойчивого развития, том 16 , 2008, стр 385-390.

7. Ouyntsetseg T, Odontuya G, Ruy Sh.Y, Kim Y.S, Quantitative determination of flavonoids and flavonols in flovers anhd leaves of Dasiphora fruticosa L., Annual Scientific Reports, 88348 2007.

8. Ладыгина Е.Я, Сафронич Л.Н, ..Химический анализ лекарственных растений, стр 171, 1983, Ленинград.

9. Тюковкина Н.А, Баукон Ю.Н, Введение, Биоорганическая химия, Москва "Медицина" 1985, стр 93-106

10. Д.Монхообор, Г.Батчимэг., Молекулын бүтэц ба спектроскопи, УБ, 2009 он, ху 100-107 